\title{
REINVENTING KOTOR AND THE RISAN BAY, A STUDY OF TOURISM AND HERITAGE CONSERVATION IN THE NEW REPUBLIC OF MONTENEGRO
}

\author{
Patrick Naef ${ }^{1}$
}

Received 30 March 2010 ; Accepted 24 June 2011

\begin{abstract}
The setting for this research is the region of Kotor and the Bay of Risan in Montenegro which are listed as protected cultural and natural heritage sites by UNESCO. The central themes of this paper are heritage preservation and the promotion of tourism. It will demonstrate how heritage can be used by certain actors in the area studied, particularly those in the tourism industry, to create an identity specific to the region of Kotor. It is assumed that there is a real determination to set the area apart from the rest of the country by highlighting particular cultural elements. The tourism sector's commitment to promote a type of tourism which it considers better adapted to the site will be put into light, bearing in mind the conservation element but also taking into account the commercial aspect. The arguments and the methods used to promote the region will be presented, showing how elements specific to the site are emphasized. An analysis of the presentation and the explanations that support the construction of this identity and the strategies aimed at developing a type of tourism specific to the Kotor site will also be undertaken. Lastly, this paper will highlight some of the consequences that tourism, and particularly certain promotional efforts, can have on the site.
\end{abstract}

Keywords: tourism, heritage, embargo, conflict, distinction, identity

Résumé: Le cadre de cette étude se situe dans la région de Kotor et de la baie de Risan (Monténégro), inscrite comme patrimoine culturel et naturel sur la liste des sites protégés par I'UNESCO. La conservation du patrimoine et la promotion touristique constituent les thèmes centraux de cetarticle. II s'agira premièrement d'observer la manière dont le patrimoine peut être utilisé par certains acteurs de la région, principalement ceux liées au secteur touristique, afin de construire une identité qui serait spécifiquement liée à la région de Kotor. L'hypothèse sous-jacente à cette réflexionest basée sur le fait qu'il existerait une volonté de se distinguer du reste du pays, et ce à travers la mise en avant d'éléments culturels particuliers. Puis, une analyse des stratégies qu'ont les instances touristiques de promouvoir un type de tourisme vu comme plus adapté au site complétera cette réflexion.Cette promotion d'un type spécifique de tourisme suit une logique de conservation, mais aussi comme il sera démontré, une logique proprement marchande.Les représentations et les discours qui accompagnent cette construction identitaire seront ensuite

\footnotetext{
1 Patrick Naef, PhD candidate, University of Geneva, Environnemental Sciences Institute, 7, Route de Drize 1227 Carouge, E-mail : Patrick.naef@unige.ch
} 
déconstruits. Finalement, certaines conséquences que le tourisme, et plus précisément les modalités de promotion de ce type de tourisme, peuvent avoir sur le site seront mises en lumière.

Mots clefs: tourisme, patrimoine, embargo, distinction, identité.

\section{Introduction}

This paper intends to analyse the processes of reinventing a region, both through the mechanisms of tourism and leisure development and through cultural and natural heritage conservation practices. The focus will be on a post-embargo context, namely in Montenegro, where ten years of conflict and embargo made it necessary to reinvent the country and change its international image. Its newly-won independence reinforced the importance of improving its reputation by distancing itself from its neighbour, Serbia, which is still closely linked to the Balkan war. First the way this country is using tourism to develop a brand image shall be put into light, specifically in a site protected by UNESCO: the area of Kotor and Risan Bay. The argument here is that the UNESCO listing is used as a kind of label that enables the region to set itself apart from the rest of the country, by presenting its uniqueness as a comparative advantage and as the motivation for seeking a type of tourism particularly suited to the site.This paper states that there is a real determination to set the area apart from the rest of the country by highlighting particular cultural elements. It will show the tourism sector's commitment to promote a type of tourism which it considers better adapted to the site, bearing in mind the conservation element but also taking into accounts the commercial aspect. Finally a close look will be taken at the impacts of the processes of reinvention of Kotor and the Risan bay area, pointing out phenomena, such as gentrification and museumification, and also the way tourism development participated to transform this site in a monofunctional space.

This paper is the result of a field study conducted during 3 month in the summer of 2006 in the region of Kotor and the Risan bay. It is based on 21semi-structured interviews with specific local actors operating in the field of tourism, conservation and territorial development. Furthermore informal interviews with tourist, content analysis and a large work of observation have been conducted all over this period.

\section{Issues: a heritage that makes the difference}

The objective in this study is to analyze the relationship of the actors in the area under study to their heritage, together with the strategies for the promotion of tourism based on the cultural heritage of the Boka, and more precisely the UNESCO listed area of Kotor and the Bay of Risan $^{2}$. The statements and the publicity used in the site's promotion as affirmations of identity and the means of building a strategy of differentiation, designed by the representatives of the tourism industry, shall be examined among others. The distinction concentrates primarily on cultural aspects and emphasizes a set of values belonging to the Boka region that constitute a specific identity for this area which, in line with the discourse of inhabitant, will be named as "Bokalian". At a national level, Nota Pantzou, one of the few researchers to have studied Kotor from an anthropological angle, points to the desire of Montenegrins to create an identity distinct from their Serb neighbors by highlighting their cultural heritage.

"[...] the view expressed here represents reflexions on the efforts of the Montenegrin state and people back then to protect and promote the Montenegrin cultural heritage and identity in opposition to Serbian one." (2006: 3)

Following this idea in a paper on the new branding strategies of Montenegro, AndrielaVitic notes that "adjacent tourist locations are distinguished through social construction and recognition of each place [...]." (2007: 3). She quotes TheanoTerkanli who points out the notion of "invited landscape":

"The development of themed (or branded) environments . . . generally goes beyond [the] de-differentiation of spaces, functions, styles and symbolisms and the deliberate

\footnotetext{
${ }^{2}$ which from here on will be referred to simply as Kotor, in accordance with widespread usage.
} 
blurring of the real with the artificial and the imaginary. It rests on the effectiveness of the idea of 'Invented' landscapes and places and aims at creating contemporary wonderlands of selective nostalgia and pseudo-idealistic visionary (Terkenli, In Vitic: 3 ).

Greg Ashworth considers heritage not as something you transmit from the past, but something that is created in the present:

"Heritage is not an artefact or site associated with past times, conditions, events or personalities. It is a process that uses sites, objects, and human traits and patterns of behaviours as vehicles for the transmission of ideas in order to satisfy various contemporary needs." (2009: 187)

In the context of Kotor, such contemporary needs could be linked to the idea of setting the country apart from the image of war, and also as it will be demonstrated later, in order to attract a category of tourists who would be more beneficial to the site. Andriela Vitic insists on the priority for the tourism industry to "clearly distinguish the Balkan's History of conflict from the serenity of Montenegro". (2007: 4) It seems also that this phenomenon of distinction takes place at a more local level and it will be stated that the cultural heritage of the Boka is highlighted in order to distinguish it from Montenegrin culture. Moreover, the creation of a specific identity for the area seems to be instrumentalised by those working in the tourism industry in order to create a form of tourism that is more appropriate from a conservation standpoint but also for revenue raising. Thus the notion of heritage will be analyzed not only as a set of values to be protected but also as a "product" to be consumed, touristically. Firstly, for most of the actor of the tourism industry, Kotor comprises two thirds of the cultural heritage of Montenegro. As a result there is a firm desire to develop a specific type of tourism in the Boka area, which tourism professionals call "cultural tourism", assimilating it with "elite tourism", considered to be more sustainable than mass tourism. This quality tourism is supposedly made up of tourists who are not only having more respect for heritage but would be ready to spend more and would be thus particularly interesting for the region's economic development.

The notion of cultural tourism or heritage tourism has been widely studied by researchers in human sciences who see in it a search for authenticity or greater knowledge. Although the desire to stand apart from the general picture of tourism in the country is a priori shared by tourism professionals and conservation specialists alike - the former seeing economic benefits, the latter advantages for heritage preservation - it can nevertheless lead to conflicts, as it will be demonstrated. This process of differentiation is reinforced by the fact that the area has been recognized by UNESCO as a world heritage site. The listing itself seems to be instrumentalised, not just for conservation purposes, but also for promoting tourism. It is being used like a brand mark or a quality label. The "UNESCO" label is used to justify a tourism "product" with a strong cultural orientation.

In analyzing this differentiation process a closer look will be taken at other phenomena directly linked to tourism promotion strategies, examining their possible effects on the site. Kotor is emerging as one of the main tourist attractions of the country, and even of south-east Europe, attracting both tourists and investors. The result is a gentrification process that empties localities of their inhabitants and turns them into showplaces for tourism. In addition, some cultural events based on traditions linked to the culture and hence to the identity of the Boka, arouse very different reactions among the local population, who sometimes see them as purely commercial and aimed solely at the tourist market. A good number of actors involved in tourism or conservation industry are afraid that the desertification of certain localities and the commercialization of some customs will damage the Bokelian identity, which is after all, also one of the main reasons why tourists in search of authenticity visit the region.

Finally, the objective will be to demonstrate that this identity must not be considered as a homogeneous set of values shared by everyone, but rather as fragmented and diverse, leading to constant confrontations and negotiations, depending on the cultural and social representations to which it gives rise. In other words, depending on whom the actors are, whether they are from the tourism industry, from sectors linked to conservation or simply inhabitants of the site, different levels of identity may be at issue. The different ways in which this identity can be experienced and interpreted will thus be highlighted. It will finally be demonstrated that the determination, particularly of the tourism promoters, to present a unified 
and clearly defined picture of the Bokelian identity is source of tensions regarding the "realities of this Bokelian identity" on a local scale.

\section{Context}

The setting for this research was the region of Kotor and the Bay of Risan in Montenegro which are listed as protected cultural and natural heritage sites by UNESCO. Montenegro is a mountainous country in which the Dinaric Alps stretch from the Serbian to the Albanian borders, leaving a narrow coastal strip along the Adriatic Sea, 2-6 kms wide and $290 \mathrm{kms}$ long. The Adriatic flows inland between the mountains towards Kotor, creating the Bay of Kotor. The capital is Podgorica. The main religion is orthodox Christianity, but there is a Moslem minority (Albanian-speaking or Bosniac) and a small Catholic community in the Kotor region. Montenegro has many of the characteristics of a country in transition, not least in the area of tourism. The country is undergoing intense development after the crisis of the 1990s, when foreign tourists deserted this Adriatic destination. For the last three years preceding the fieldwork and even more so in 2006, fairly large numbers of tourists from all over Europe, and even North America, have visited the country and its main sites of interest. At the same time, tourism areas have been undergoing an «investment boom ». Foreign investors, many from Russia and the United Kingdom, are taking advantage of the relatively low prices to buy land and build, often for purely speculative purposes.

\subsection{From embargo to independence: shedding the war image}

On 21 May 2006, 55.4\% of the Montenegrin electorate voted for the country to separate itself from Serbia and become an independent state. Many people insisted on the psychological impact for tourism as the country cast off the image of war linked to Serbia. They felt their country had suffered for years from the negative reputation of its neighbor. According to Zoran Zivcovic, director of the Tourist Organization of Kotor, "In separating ourselves from Serbia, we distanced ourselves from the negative war image associated with it. If we had separated earlier, I think we would be in a far better situation today. Like Croatia, this was developing its tourism while we were still under embargo"3. Although Montenegro was virtually untouched by the Balkan conflict in the 1990s, it nevertheless had to cater for 25,000 refugees and above all bear the consequences of the economic sanctions imposed by the international community on Serbia-Montenegro. In the context of the Kotor site, relations between Montenegro and UNESCO came to a complete halt. Contact was renewed only in 2002.

Before independence, $75 \%$ of the economy was based in Serbia. Today, apart from an aluminum factory near the capital and food production for the local market, tourism is Montenegro's main industry. Government authorities see it as a key factor for the country's economic development. The end of the embargo was greeted by the return of foreign tourists, first from neighboring countries, then from Western Europe. Actors in the tourism sector described the time the field study was carried on as a transition period, in which there was a drop in local tourism and a progressive return of foreign tourism. The determination to attract Western tourists is moreover one of the key elements of the country's tourism policy, an approach that is particularly in evidence in the Kotor region. The head of the Hotel Management Department at the tourism faculty of Kotor, Andriela Vitic, remarked: "Western tourists are slowly coming back, but only for short visits. They take an organised tour of Croatia, for example, which includes a one day trip to Kotor"4. This determination to attract Western tourism is explicitly institutionalized in the document "Touristic Masterplan for Montenegro". This strategic document divides Montenegro into three distinct cultural areas:

"The coast was influenced by Venice and somewhat by the Habsburgs with some remarkable small towns: Kotor, Perast, Herzeg Novi, Budva, Ulcinj. The Highlands can be described as Slav-peasant-orthodox. The South and Northeast have an Ottoman-Islamic character" (Touristic Masterplan for Montenegro, 2001: 10)

\footnotetext{
${ }^{3}$ Kotor, July 2006

${ }^{4}$ Kotor, July 2006
} 


\subsection{Main landmarks of the region's history}

A region's history helps to explain a community's relationship with its geographical setting and the Bay of Kotor has been deeply influenced by the many civilizations that have lived there. First ruled by the Illyrians and then the Romans, it became part of the Byzantine Empire in the fifth century A.D. Seven centuries later, Kotor was integrated into the Raska, a medieval Serb state, then ruled by a Croatian-Hungarian king and later a Bosnian king. The city of Kotor enjoyed a brief period of independence from 1391 to 1420, when its citizens placed themselves under the protection of the Republic of Venice, This long period within the Venetian protectorate, which ended in 1797, had a remarkable influence on the region's culture. After Venice, the region was governed successively by Austria, Russia and France. Under Austrian domination again, from 1814 to 1918, it then became part of the Kingdom of Serbs, Croats and Slovenes, transformed into the Kingdom of Yugoslavia in 1929. Occupied by Italy during the Second World War, at the conflict's end Montenegro was one of the six entities making up the Federal Socialist Republic of Yugoslavia. The Bay of Kotor has thus been part of Montenegro only since the $20^{\text {th }}$ century. Another fundamental influence on the region's history which until the $19^{\text {th }}$ century was accessible only by sea - is its maritime tradition. Kotor and its surroundings have always been an important hub and commercial centre, but it is also famous for its schools of navigation. Finally, numerous earthquakes have marked Kotor's recent history. The last, in 1979, destroyed two-thirds of the old town of Kotor, which was closed to the public until 1987.

\subsection{UNESCO Heritage site listing}

The perimeter classified as a UNESCO World Heritage Site comprises the city of Kotor and the whole of the Bay of Risan. Montenegro calls it Home of Natural and Cultural Heritage. However, when the site was listed, UNESCO did not have a "cultural landscape" category. As a result, the site is listed with UNESCO in its C category, which includes culture, but not nature. Changing the categorization would be a lengthy procedure and for the moment the objective of Montenegrin conservation professionals is to maintain the site's listing, rather than to change its category. The site includes some thirty localities, along the bay coast and inland. The main town is the walled city of Kotor, at the bay's farthest inland point, with Mount Lovcen behind it. Other points of interest are the villages of Risan, Prcanj and Perast, on the edge of the bay. The entire site is under the sole jurisdiction of the Municipality of Kotor. According to its head of urbanism, Petar Zivkovic, "the municipality contains $40 \%$ of Montenegro's cultural heritage, in terms of buildings: churches, old towns, under-water ruins, and even mosaics. All these elements are under our protection. We must be aware of this and of the huge responsibility it implies." ${ }^{5}$ For Katarina Nicolic, an architect who is very involved in the conservation of the site, the municipality's control of the entire site is a problem. "Being very independent, the municipality can decide everything. This is a big problem. It should be much more balanced. "

The site was included in UNESCO's World Heritage Site listing in 1979, in recognition of the authentic and unique characteristics of its architecture and of its considerable influence on the region. The bid for inclusion in the UNESCO's World Heritage list was submitted by the Republic of Yugoslavia on the $27^{\text {th }}$ of September 1979, following an earthquake which damaged $70 \%$ of the constructions in April of the same year. Many palaces, houses and monuments, including Romanesque churches and the town wall, were destroyed and the old town of Kotor was evacuated by all its inhabitants on the $15^{\text {th }}$ April 1979. After this disaster the restoration and consolidation of Kotor's cultural heritage was included in the general reconstruction of Montenegro. Amadou-Mahtar M'Bow - the Director General of UNESCO at the time - launched an appeal to mobilize international solidarity which raised $20,000 \$$ directly after the earthquake. The site was also included in the World Heritage in Danger list. The following years, until 1989, technical and financial assistance was provided by UNESCO through its regular and extrabudgetary sources, including the World Heritage Fund. Throughout the 1990's, during the turmoil in the region and the ensuing embargo, the World Heritage Committee lost all contact with Montenegrin authorities and local conservation bodies.

\footnotetext{
${ }^{5}$ Kotor, July 2006

${ }^{6}$ Kotor, July 2006
} 


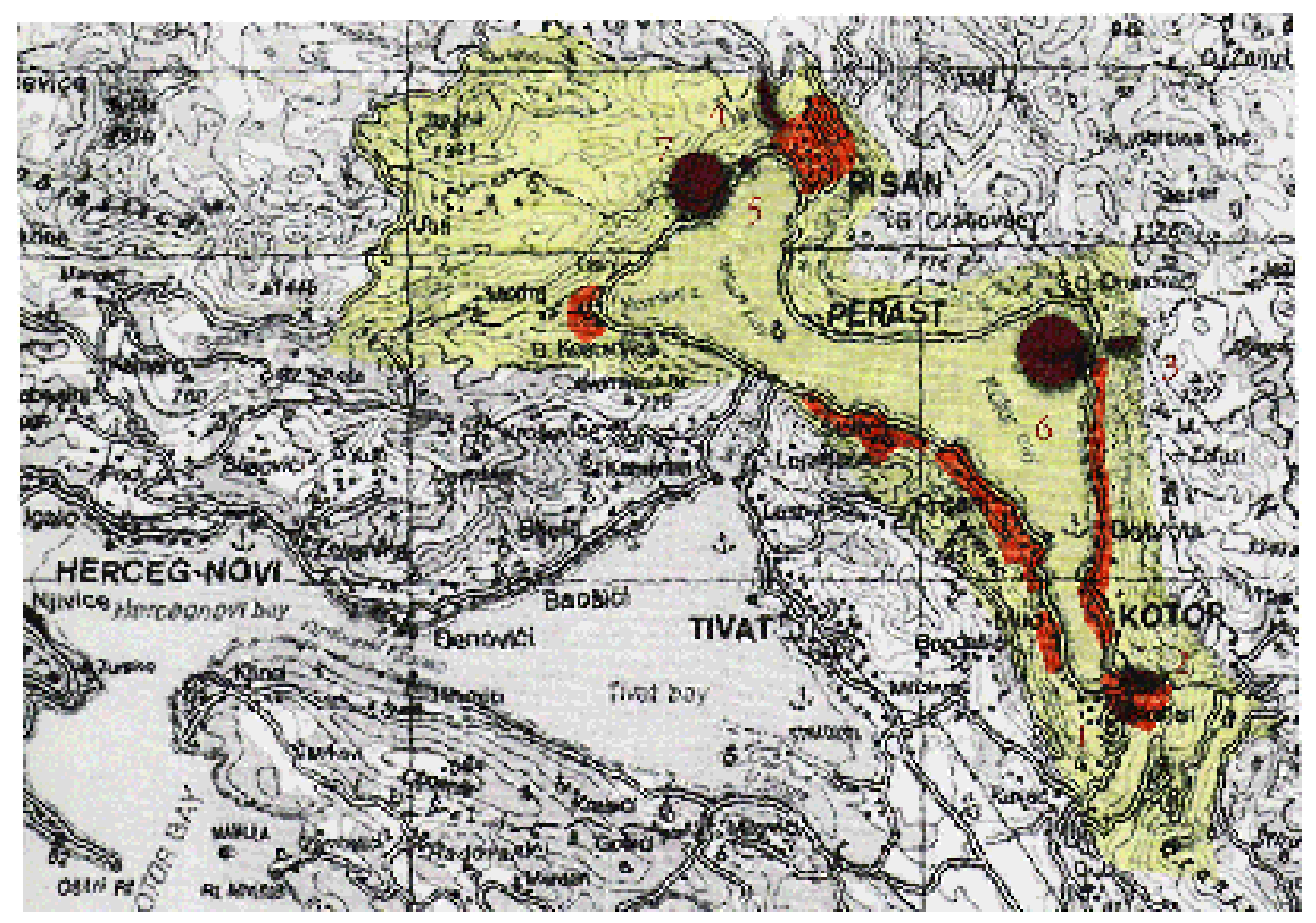

Fig 1. Map of the area inscribed to the UNESCO listing (Ministry of Culture, 2005).

It's only in June 2002 that a joint UNESCO-ICOMOS mission visited the site again and recommended removing Kotor from the List of World Heritage Sites in Danger ${ }^{7}$. This was officially done in July $2003^{8}$. The UNESCO experts nevertheless stressed that the site was under threat from uncontrolled growth, also clearly visible along the entire Montenegrin coast. They recommended that a report be prepared proposing guidelines on conservation and consciousness-raising. Interdisciplinary groups were working on a Management Plan which was due on 1 February 2007. The Kotor region, like the rest of the country, experienced a sharp drop in standards of living during the embargo. This led to the development of informal and Mafia-style systems which still flourish. The tourism sector also fell prey to this phenomenon, as these comments from Zoran Zivkovic, the director of the Tourism Organisation of Kotor, show: "We have a big problem with the inhabitants... during the embargo a large black market developed. These illegal practices, which could perhaps be justified during the embargo, still exist. In Kotor as in the rest of the country a mafia-style capitalism is still prevalent. For example cigarette smugglers who made a lot of money during the war are now investing in real estate or the hotel business." In such a context, there are few controls on the investment boom in the country and most particularly along the coast, leading to illegal urban development, which is threatening the site of Kotor. Sacha Karajovic, urban planner for the city of Kotor, describes the process in a report on the spatial development of the city:

"Some reconstructions were not successfully done so they have lost characteristics of the time they were created in; some buildings and areas were not used in an appropriate way. New illegal or inappropriate buildings (especially seasonal and holiday houses) were built near very nice and old settlements." (2005: 3)

During their last visit to the site UNESCO, experts warned the authorities concerned of the dangers this kind of urban development represents and pointed to the difficulties the authorities were experiencing in applying the law:

"The situation is made worse by the non-observation of the regulations of the spatial plan (or the conditions laid down in individual building permits) by undisciplined and often unscrupulous promoters". (World Heritage Committee, 27th session, 2003)

\footnotetext{
${ }^{7}$ World Heritage Committee, 26th session, Budapest, June 2002.

${ }^{8}$ World Heritage Committee, 27th session, Paris, June-July 2003.

${ }^{9}$ Kotor, August 2006
} 


\section{Theory and Concepts}

Part of the research belongs to the anthropology of tourism, while other concepts, like memory and history, are related to the ethnology of heritage. Concepts linked to tourism and to heritage will first be presented, and then a close look to the notion of a region will be undertaken, with the capital role that heritage plays in constructing a regional identity. Concepts of gentrification and place identity - more linked to a geographical approach - will appear. Overall, an interdisciplinary approach will be undertaken, essential for a clear understanding of the social phenomenon of tourism.

\subsection{Cultural tourism and commercialization}

Today, mass travel has made "cultural tourism" a popular, if nebulous phrase. Cultural tourism is perceived by ICOMOS as "niche tourism", educational and frequently up-market. Consumers are supposed to be well educated and eager for authenticity. In the academic world, views on what constitutes cultural tourism vary. One view is an association of leisure and culture. Another identifies a melancholy for the past. Others link cultural tourism and eco-tourism. Likewise, the tourists themselves are hard to define, though there is general agreement that they are mainly Western, well-educated and, above all, well-off. These factors are a key element in this work, since Kotor is aiming to attract just this kind of tourism. François Ascherissues a warning linking "cultural tourism" to the notion of luxury:"luxury tourism is a versatile and unstable market that can lead to a banalisation of the tourist offer" (1984: 76). As it shall be demonstrated, Kotor is moving in this direction, which is already having effects on the site, one of which could be this type of banalisation. Other concepts besides cultural tourism also need defining. Commercialization, which frequently accompanies the development of tourism, may have repercussions on life in general at a tourist site, and not just on tourist related elements. Kotor seems to be typical of a site where tourist attractiveness is affecting its general evolution, with implications on the life of its population reaching far beyond the tourism sector. At issue is the use of a place's heritage as a resource for promoting tourism, as something that is "consumed" by tourists. A commercial view of heritage will be put into light, which sees heritage as a product or resource for which there is a demand, and tourists as the consumers.

\subsection{Heritage lends validity to a region}

In an increasingly globalize world, heritage appears as a safe investment protecting us from the dilution or disappearance of our identity. It can be an instrument that helps to mould or reinforce an identity, by protecting the historic and cultural particularities of a region. This raises the question of the definition of a region. In this context, the Boka, most of which lies within the protected site of Kotor, and where efforts are being made to distinguish it from the rest of the country, qualifies as a region and will therefore be included as so in this analysis. Authenticity can closely be linked to the notion of a region. Regions emphasize that they are older, more original or authentic, than the nation state and possess elements that the state does not have. Thus the Boka region contrasts its long history, going back to before the Romans, with that of the Republic of Montenegro, which is barely one year old. Cultural heritage gives legitimacy to the specific elements that set a region apart. Local history creates a collective identity.

\section{Defining the region's cultural specificity}

Both people working in the tourism sector and the general population help to define the Boka region's specific character, a profile which is accentuated by its UNESCO designation. Its distinguishing features are, in their view, historical, natural and cultural. Historically the region's varied history, but particularly its centuries under Venetian rule, are highlighted, in contrast to the Ottoman links of the rest of Montenegro. Culturally, the authenticity and originality of its architecture, towns and villages and customs are highlighted. Naturally, the bay of Kotor is billed as unique-- "the only fjord in the Mediterranean". It's first interesting to point out that if the bay of Kotor is always identified in every promotion material on the region as a Fjord - the only one in the Mediterranean - this bay doesn't match the scientific definition of a Fjord, but should rather be named as a canyon. 


\subsection{The UNESCO brand: a special distinction}

It is difficult to ascertain to what extent the UNESCO designation has helped to conserve and protect the site. The report written in 2003 following the mission undertaken by UNESCO and ICOMOS was not very positive:

"Protection and conservation of the landscape seems to play a relatively insignificant role, both institutionally and as concerns a public awareness $\left(27^{\text {ème }}\right.$ session du Comité du Patrimoine mondial, 2003: 4) ${ }^{10}$

UNESCO observed that the population seemed unaware of and unconcerned by conservation issues and both UNESCO and conservation specialists agree that this lack of concern had led to uncontrolled building and even to the destruction of heritage buildings. UNESCO brought help in terms of technical equipment and training, and above all sent experts promoting special measures to raise the population's awareness of heritage issues. However, rather than exploring awareness raising issues, the purpose here is to look more closely at how the UNESCO designation is contributing to promoting the site. Based on some empirical observations, it seems to plays an important role. One of its effects is to give a special aura to a site, presenting it as a sanctuary or a reservation with a clearly defined image, and increasing respect and interest among tourists. This statement of Kotor tourism board director Zoran Zivkovic testifies to the importance of the UNESCO designation: "It's very important for tourism in Kotor. People from outside hear more easily of the place. It's a kind of advertising, a brand."11 And Nota Pantzou, based on her research in Kotor, notes that: "the majority of those whom recognize the potentials of sustainable tourism development and involve themselves actively in the tourist industry, deem the World Heritage designation of great importance» (2006: 3)

Kotor's World Heritage listing is systematically featured in tourist publicity and regularly referred to by tourist guides. The designation seems to be used like a "label of quality" and the site perceived as a "product" guaranteed by the UNESCO label, as stated by Sasha Karajovic: "With Kotor we have got a valuable product and cultural events"12 or even Henic Strahina: "We try to build Kotor as a unique product". ${ }^{13}$ Following the idea of distinction, the protected area is presented as a cultural "product", guaranteed by its "UNESCO brand".

In the existing literature, this conceptualization of heritage in terms of production consummation can be observed in Patrice Beghain's work: "We can't ignore the fact that tourism and heritage are linked; the same way than our beaches and mountains, our monuments and our museums have become a new tourist product [...]" (1998: 38)This quote from Pharès, extracted from an official UNESCO publication, also connects with the idea of UNESCO branding: "Observation shows it: The UNESCO inscription involves in more or less time, a significant raise of tourist activity, now that the UNESCO status became a «quality label» valorized by the tourism industry or by the local authorities as a tourist development tool." (Les Cahiers du patrimoine, 2002: 91) Furthermore and in another context, referring to his research on the "Pays dogon" (Mali) where part of the region is also listed by UNESCO as a natural and cultural site, Gaetano Ciarcia notes that UNESCO "has the ability to deliver a kind of " guarantee designation of origin ${ }^{14 "}(1998: 108)$ he adds that this process tends to create a reified tour of "representative villages" to protect.

The previous paragraph demonstrates the way the primary goal of UNESCO (conservation) seems to change and become instead a kind of brand. If tourists are seen as consumers, then the product "Kotor and the Risan Bay" can be worth their trust because of its UNESCO brand. It seems clear that the listing of the Kotor site influences the way the various actors perceive it. It is also often stated that a UNESCO listing means that a site does not belong to one nation but to the entire world. Radenko Curcic, referring to the historic center of Kotor notes that: "This town belongs to the whole world. We - Montenegrins - are not simple owners of the site."

\footnotetext{
${ }^{10}$ Written in the text in French : La protection et la conservation de paysage semble jouer un rôle relativement insignifiant à Bokakotorska, tant du point de vue institutionnel que du point de vue de la conscience de la population »

${ }^{11}$ Kotor, July 2006

${ }^{12}$ Kotor, August 2006

${ }^{13}$ Podgorica, July 2006

${ }^{14}$ Appellation d'originecontrôlée $(A O C)$ in French in the text
} 
Furthermore, in the Malian context, Ciarcia points out that the site is "close to being deterritorialized under UNESCO". (1998: 108) This process can finally be illustrated by this statement in a document published by the Montenegrin Ministry of Culture:

"What makes the concept of World Heritage exceptional is its universal application. World Heritage sites belong to all the people of the world, irrespective of the territory on which they are located" (UNESCO World Heritage sites in Montenegro, 2005, p.4)

To some extent, the notion of territory gives way to a universal interpretation of World Heritage, in which sites belong to all the peoples of the world, irrespective of the territory where they are located. Kotor, from this standpoint, would not even be part of Montenegro (although it should be borne in mind that UNESCO provides only recommendations and limited aid and that ultimate responsibility lies with governments). Nonetheless, this argumentation suggests a separation from the sovereignty of a state and, when voiced by local tourism officials, could be interpreted as a desire to stand apart.

Still related to the idea of UNESCO branding, it would be interesting to take a close look at the utilization of the UNESCO logo. Nota Pantzou states that:

"Kotor is a major heritage attraction for the Montenegrin state and UNESCO's logo is widely used for marketing, tourist and political purposes. [...] Moreover, the emblem of World Heritage appears on every tourist brochure, card, sign, on official municipal or government websites [...]" (2006, p.3)

Signage and print media are elements that consistently emphasize the UNESCO logo. Jane Lennon in a UNESCO publication stresses the importance of the UNESCO logo use: "The use of the World Heritage logo as an awareness device and marketing brand is also to be encouraged in promoting the inscribed cultural landscape"(Les Cahiers du Patrimoine, 2002: 121)First it can observed that on the three main roads leading to the Bay of Kotorare installed several square meters panels indicating the name of the site and its cultural and natural heritage status. In addition, as noted by Nota Pantzou, it is very rare to find a prospectus, or even a poster, without the UNESCO logo. Plans of the city, cultural programs and most tourist brochures are marked, if not with the logo at least with a reference to UNESCO.

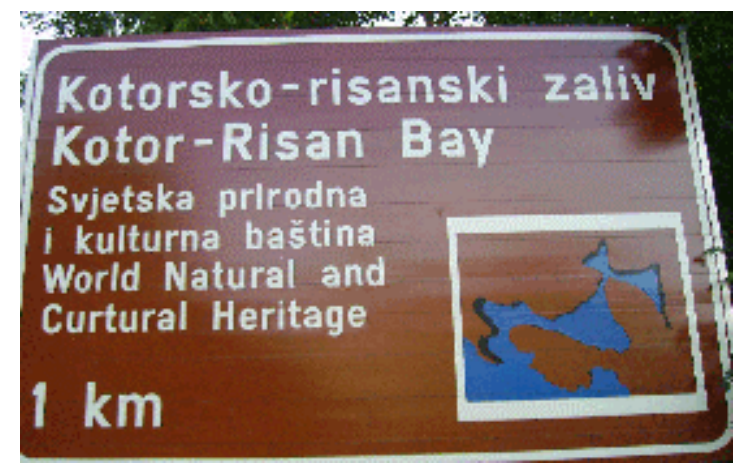

Fig 2. On the road to Kotor... (From the author, 2006).

The goal of the UNESCO logo is part of ICOMOS recommendations and it should always appear with another one drawn up especially for each site:

"All designed and strategically placed signs serve an important role in any site's overall interpretative program. If at all possible, a readily comprehensible logo unique to the site should be developed for use in conjunction with the World Heritage logo. It should be used on all signs, maps, printed materials related to the site" (Tourism at World Heritage Sites, 1993: 51)

Following this last recommendation, the logo related to the site of Kotor is systematically displayed with the UNESCO logo, considered by Arthur Pedersen as an emblem having: "a fund raising potential that can be used for increasing the market value of products with which it is associated". (2002: 17) 


\subsection{Culture as a distinguishing feature: the Boka festivities and the Bokelian Identity}

In summer, a variety of cultural events, some of them quite recent in origin, are organized for the tourist season. The two most important and best known events are the Boka Night and the Summer Carnival. Boka Night lasts one night and is organized by the Kotor Municipality; the Carnival lasts five days and is organized by a private committee, with extensive support from public bodies such as the Kotor Municipality and the national tourism organization. The Boka Night is the biggest summer event in the entire country, in terms of the crowds it attracts: around 30,000 according to most estimates. In 2006, the fete took place on 19 August. It started with a parade of decorated boats, resembling Venetian gondolas and satirizing events of the year. The second half of the evening was devoted to a fete in the old town. The cafes cleared their terraces and the entire historic center was transformed into a dance floor, with DJs providing a mix of European and local music. Participants were mostly young people from nearby who knew the words to all the local songs. Although the event is supposedly "organized for tourists", according to empirical observations the people attending and the references during the evening were local, while the foreign tourists met at that time seemed on the whole not interested or attracted by the event. In this case, are the tourists who are targeted mainly local people and does the description "for tourists" reflect a certain disenchantment with the commercialization of traditional festivities?

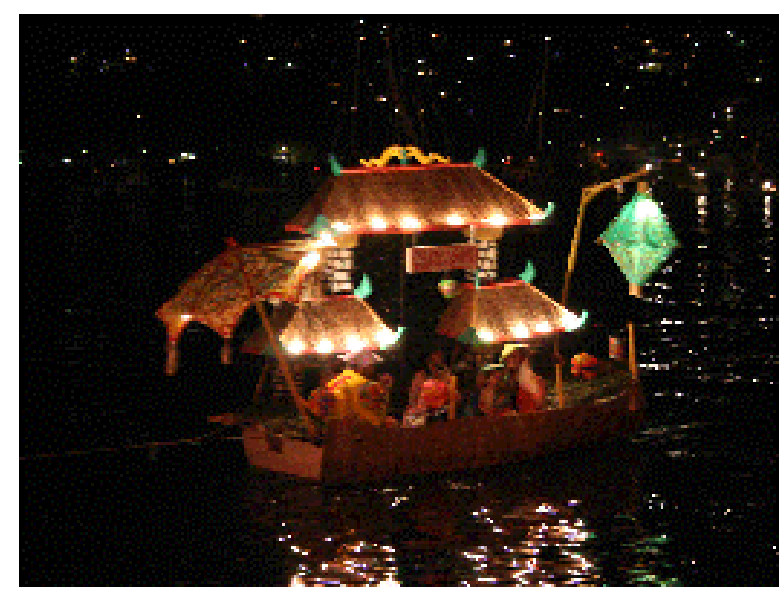

Fig 3. A Chinese gondola during the Boka Night (Naef 2006).

In February, a winter carnival honors St Tryphon, the patron saint of Kotor, attracting large crowds for its presentation of the life and customs of the Boka's seafaring inhabitants. Six years ago, a summer festival, described by its organizers as a summer version of the traditional February festival, was launched. It is perceived in some quarters as above all a commercial version of the winter carnival. In 2006, the summer festival was held from 1 to 5 August. Each day visitors were invited to sample regional culinary specialties, attend theatre performances or watch fancy dress parades. Highlights were a fancy dress competition and a big party, mainly for young people, in the old town.

The strong desire in the region to create an identity that is distinct from that of the rest of the country has already been pointed out. An attempt will now be made to define the different components of this specific identity and then to determine which elements represent World Heritage values and attract tourists. It is important to remember that the Boka region has been Montenegrin for less than a century. By its geographical position, it has been turned in on itself - and cut off from the rest of Montenegro, since it was accessible only by sea until the first roads inland were built in the $19^{\text {th }}$ century. "Kotor and Montenegro do not have the same history" is a recurrent phrase in the area. Since the present-day tourist image of a place helps to create a specific identity, it is interesting to look at the historical references that are specially emphasized. The local population and more particularly tourism professionals stress that Kotor and its region has strong links to Western culture, in contrast to the rest of the country, which is closer to Ottoman and Islamic culture. For tourists, and particularly Western tourists, it is part of the heritage of Western civilization. Kotor was a Venetian protectorate for more than three centuries (1420 - 1797) and the population looks back with pride and nostalgia on this period. References to the Venetian heritage are numerous, the most important being the summer 
carnival described in the previous chapter, and the arms of Kotor (widely used in promotional materials) composed of St Tryphon, the town's ramparts and the lion of St Mark, the protector of Venice.

The seafaring tradition of the Boka is also an essential element of the area's identity. It was known not only for its port, but for the high quality of its seamanship training center. One can notice the numerous references to the area's tradition of navigation, the fact that the only two museums in the protected site are maritime museums, and also the prominence given to seafaring history in several coastal villages. Today, maritime history is evoked in support of the construction of a marina in Kotor, reaffirming the rich seafaring tradition of Koto and is reflected in the Boka Night, where many of the competing boats adopt a nautical theme. Maritime history is thus used to promotional ends. Finally, what are the values attributed to the Boka region and its inhabitants and how are they justified? The Boka's maritime culture and geographical situation are often cited as having produced a culture of tolerance and respect for other religions, races and civilizations, and even a certain festive spirit. These characteristics are also attributed to the region's historical links with Venice, leading Kotor to adopt the multicultural and multi-religious outlook of its protector. Catholics predominated in Kotor until its incorporation into Montenegro in the early $20^{\text {th }}$ century, when the balance swung to an Orthodox majority. In part because of the large number of mixed marriages, the Catholic churches are still functioning. However, there is not a single mosque in the area, and religious multiculturalism seems confined to Christianity.

\subsection{Memory and current issues}

Besides helping to create an identity, historical elements can also be used to justify or influence present day actions or projects. The two examples that follow illustrate this process. In the midst of illegal building and opposition to some tourist development projects, one project seems to win unanimous approval among tourism promoters, inhabitants and conservationists: a cable car linking the old town of Kotor to the Romanesque church of St Mary, directly above it and currently accessible only by climbing 1,400 steps. The project, which would facilitate access to the church for tourists, is backed by the Austrian government. It should be noted that a cable car existed previously during the First World War to supply Austrian troops and that the promoter of the current project is the grandson of the engineer who built the first cable car. Most of the interlocutors of the field were in favor of the project, including those involved in conservation, who are usually more skeptical about tourism development in Kotor. They argued that it was an idea featured in old plans, that there had been a previous car, that the promoter was linked to Kotor's history, that it was a good way of using history. The main point was to protect the view of the fortress and to revitalize the church, which could not be done otherwise. The project seems to be a good example of how historical elements are used to justify a development whose principal target is the tourist market.

A second example in some ways contradicts the cable car issue. After the Second World War, Marshal Tito who wanted to commemorate the liberation, replaced the lion of Venice above the main gateway to the old town of Kotor with a Communist star and an inscription "Tude necemo, svoye nedamo" (We want nothing foreign, and will not relinquish what is ours.) The lion was thrown into the sea. Recently there have been various moves to rehabilitate the Venetian lion and remove the inscription. The reactions are interesting: "We should recreate the lion...A replacement lion wouldn't be authentic."15“" Even if I hate the words, they are part of our history." "16“" Conservation aims at preserving what is authentic and what's more, you have to respect all the phases of the history of a monument. But is history as recent as the Tito period already part of history?"17" Many things change in history. We have to preserve our heritage. It wouldn't be honest to make a copy."18 Clearly, however strong was their opposition to the Tito inscription, most would not want to replace it with an unauthentic lion. It seems that attitudes to the past are closely depending on the context.

\footnotetext{
${ }^{15}$ Smiljka Krivokadic, employee at the Conservation Institute of Kotor, September 2006

${ }^{16}$ Lidija Liesar, Employee at the Minister of culture, August 2006, Podgorica.

${ }^{17}$ Illia Lalosevic, Director of the Conservation Institute of Kotor, September 2006

${ }^{18}$ Sandra Kapetanovic, architect and founder member of the NGO Expeditio, Kotor, August 2006
} 


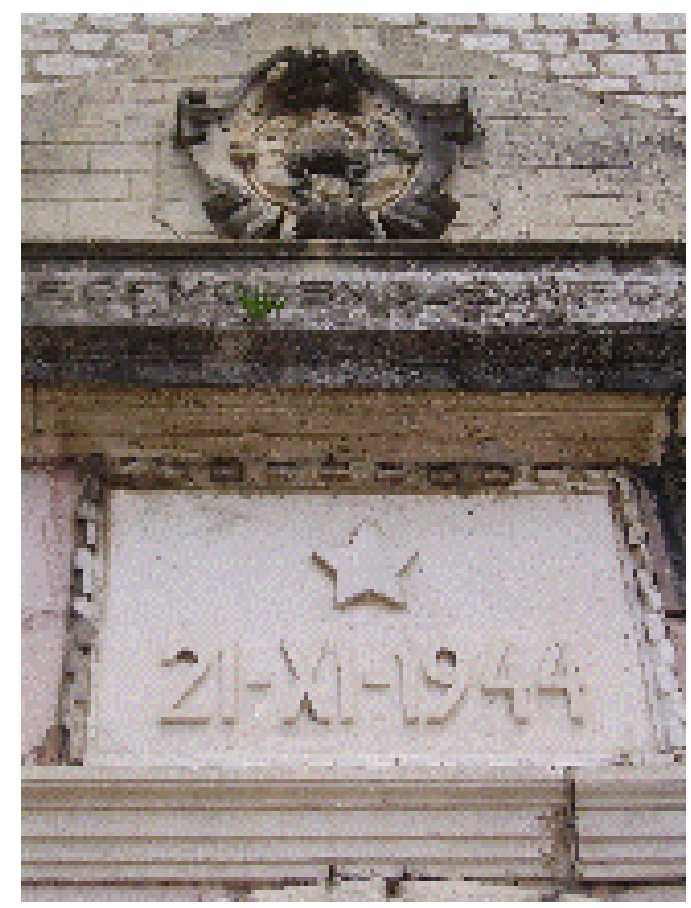

Fig 4. "Tude necemo svoye nedamo" (Naef, 2006).

\subsection{The limits to instrumentalising history}

After analyzing these two examples one can see that in the first case historical elements are used to justify a large-scale tourism development project. In the second case, the desire to replace a recent historical element that for some is traumatic by rehabilitating a historical feature from a more distant and perhaps more positive past comes up against the importance of the notion of authenticity. Jonas Frykman looks at the question of what freedom people have to create the most appropriate image of themselves. "People are free to control their own history (...) they transform the past into a culture heritage which they are willing to make their own. Tradition does not force itself on the individual. We are relatively free to create a heritage for ourselves." (1999: 18) People, he maintains, can select historical elements "to create an attractive self portrait - usually with a strong local connection". But this view, he warns, which he terms "modernist", gives the individual too much freedom to construct his culture. He is then someone who "interprets and handles meaning, rather than one who acts." (1999: 18) Following this idea, is the individual an instigator or someone confined by his cultural patterns, an external structure? Frykman quotes Thomas Ziehe and his contrary view that individuals "make their way to ontological orders that existed before them, which are not influenced by them". (In Frykman, 1999) These two opinions bring us to the notion of memory. Frykman sees it as a symbolic power "which can be used to support different discourses". For Jean Werner Muller, memory is "not really what people recollect, but how they manage to make sense of the past (...) it is not a vessel of truth or a mirror of interests, but a process of constructing meaning." (2002: 30) Memory is thus not the same as truth and Hewison goes so far as to say that heritage is gradually wiping out history, "by substituting an image of the past for its reality" (In : Prentice, 1993: 42). The Tito inscription case shows that however strong the desire to substitute a past viewed as positive (the Venetian period) for a past seen as negative or ambiguous (the period of socialism) -- and in total opposition to the image of tolerance highlighted by those involved in promoting Kotor -- the notion of authenticity is primordial. As Beghain makes clear: "One thing is missing from the most perfect reproduction: the here and now of the work (...) the here and now of the original forms the concept of its authenticity" (1999: 45) He goes on to say "that a reproduction, by negating the authenticity of a work, can threaten the quality of its historical witness".

These examples seem to demonstrate how the use of traces and artifacts from the past and, by extension, elements of identity, can lead to conflicts. The cable car project illustrates how historical facts can make an urban project historically compatible, while the Tito inscription shows that history cannot be manipulated by individuals. On the one hand the massive 
construction of the cable car could be seen as a threat to the authenticity of the landscape; on the other hand, authenticity is preventing the removal of the Tito inscription. Frykman argues that people tend to attribute an "aura" to historical artifacts, but asserts that objects have their own unique aura. Based on what is has been written previously it seems quite obvious that the Tito inscription has such an aura and that it influences how people react to it. The conflicts that arise from it are proof of this and this historical element cannot be looked on solely as an objective witness of the past. Reverting to Frykman's and Zeihe's remarks, one could conclude that individuals are not confined in an ontological order that they are unable to influence, nor are they completely free to use history as they wish.

\section{A distinct culture making an economic difference}

It will now be shown how the process of cultural distinction already described an also serve economic goals. The widespread insistence on the specific character of the region has to some degree been instrumentalised in order to set the site apart from the rest of the Montenegrin tourism scene. Based on empirical data, like strategic documents on the development of tourism, the objective now is to demonstrate how the priority for the site is closely linked to the promotion of a sort of elite tourism, often assimilated with cultural tourism. The choice is motivated partly by conservation goals, cultural tourism being perceived as more appropriate than mass tourism for heritage preservation. But purely economic goals also play a role, since many of the actors in the tourism sector see elite tourism as financially more interesting. Some maintain that an increase in the price of services linked to tourism would help to reinforce the distinct nature of the site. Culturally, Kotor seems to promote a specific identity, which can also be observed in economic terms, if one looks at how its "up market" status is presented. One can be struck on arriving in the old town of Kotor by the number of boutiques offering luxury items, or at least better quality goods. The old town offers to the public one jewelry shop, half a dozen clothes shops and three hairdressers. They are all well above the average standard which can be seen elsewhere in the country. One significant example can be observed in the choice of post cards on display. At least in the old town, there are no signs of cards featuring provocatively posed nude women or other subjects generally qualified as vulgar that are available everywhere else in the country. It is also interesting to note that the choice of post cards is even dealt with in the ICOMOS recommendations: "Postcards and posters can be splendid, profitable and reliable marketing tools if they are well-produced". (1993: 29)

Now it would be interesting to take a brief look at how some of the European tourists see the site. Some, like Gabriel ${ }^{19}$, a French tourist, has the feeling that they "aren't in Montenegro anymore". Andy, a British tourist sates: "It's no longer the third world.... it's the only place in the country where I could spend a week or two". For Greg, a Swiss tourist, the site brought to mind "St. Tropez or Porto Vecchio, but with more history. And the people who work in the restaurants and hotels seem to be more tourist conscious. They are more friendly, they speak other languages. It's better than the rest of the country where they treat tourists like fools." Emma, a Spanish tourist, explains she found the site "very rich, very European, rather south of France.... not at all like the idea one has of east European countries."But those positive voices shouldn't occult some critics also expressed by other western tourists, like Alice form Switzerland who notes that "There are only fancy restaurants here... There is no life!" Or even this French teenager who complains about "all the souvenirs shop present in every church..."Finally, a more local reference: the following paragraph is from an article that appeared in Danass, one of the main newspapers of the region, which illustrates well what the process of upgrading happening in Kotor. "There's no point any more in going to St. Tropez to meet celebrities. A better bet is the Montenegrin coast where you can run into Michael Douglas, Roman Abramovitch, the Chelsea club owner, or the mayor of New York, Michael Bloomberg. Stars and politicians from all over the world are investing massively in real estate and prices are soaring." 20 This particular quotation refers to the Montenegrin coast, but most of the article cites the case of Kotor to describe the process by which the very rich are moving into the region.

\footnotetext{
${ }^{19}$ The names of all the tourists are fictive.

${ }^{20}$ The jet set takes over Montenegro, Danass, $5^{\text {th }}$ of December 2006.
} 


\subsection{The Masterplan, or the promotion of "elite" tourism}

The Touristic Masterplan for Montenegro is an official document that lays down guidelines for tourism for the next fifteen years. Published in 2001, it was drawn up by the Montenegrin government in partnership with a German firm of consultants, DEG. The Plan fixes precise objectives, including the development of specific types of tourism (beach holidays, ecotourism, cultural tourism, etc) depending on the characteristics of the various tourist destinations in the country. Richard Prentice describes this strategy in his book: "A place-product can be sold in more than one tourism market, emphasizing different aspects of a place to different groups or segments of tourists" (1993: 4) François Ascher takes the same view as Prentice: integrated planning requires "choosing the types of tourism best adapted to the general characteristics of a place". (1984: 85). In the case of Montenegro, this differentiation is generally summed up in the following extract from the Masterplan:

Diversification will continue in scale of management and through specialization. This bound up with the basic qualities of the regions (e.g. Boka Kotorska = high quality, Tara river $=$ nature, towns $($ Budva $=$ middle class, Tivat and Sutomore $=$ basic $)$ and locations (Ulcinj = family, all standards)". (2001: 3)

For the bay of Kotor, which this strategic masterplan recognizes as one of the main tourist destinations in the country, "quality" is a priority. Taking this view, tourism-related bodies advocate the development of cultural tourism:

"Due to its specific characteristics, the municipality of Kotor and the town of Kotor should offer specific types of tourism that need to be different from typical hotel and beach tourism. Therefore, having the rich history, heritage and numerous traditional customs and festivities, the area of Kotor should develop the cultural tourism with the overall presentation of its heritage". (Touristic Masterplan for Montenegro, 2001: 6)

The other central point of this document is the desire to attract western tourists, who are seen as more beneficial for the tourism industry than local tourists: "With its product qualities, the site can only attract small numbers at present from Western Europe" (2001: 13) This outlook is confirmed by Dragana Vukadinovic, a staff member of the Kotor tourism organisation: "We are trying to attract European tourism, mainly from Western Europe. Local tourism is much less interesting. This year, overall, the number of tourists has not increased, but there has been an increase in European tourists and a drop in local tourists." ${ }^{21}$ In keeping with this approach, a regional masterplan centered on the bay of Kotor has been established. The site, said to contain two thirds of the country's cultural heritage, is singled out for cultural tourism and defined as an "elite zone". Thus, quality tourism is explicitly linked to Western tourism:

"A high quality product first for Western and Northern Europe that progressively replaces the cheap offers and is ultimately equated with Montenegro's tourism industry." (Touristic Masterplan for Montenegro: 6)

This approach conforms to key words in the masterplan that define the country's different tourism destinations. Those attributed to Kotor and the Bay of Risan are as follows:

"Anbiance leisurely, expensive and exclusive. Small, well-tended hotels and guesthouses, restaurants, wine bars, cafes, dancing, bathing terraces at the fjord, parks, cycling routes, hiking trails, walks, golf, casino, fitness, health, marinas, boat trip and excursions, museums, music, folklore, galleries, congresses, conferences." (2001: 15)

The description of the city of Kotor aims even higher: "Ambiance royal seat. Health resort of urban upper class, culture (...) theatre, concerts, gastronomy..." (2001: 16) In practical terms, this means, according to Rade Radkovic, professor at the Faculty of Bar, "developing "Palate", or small quality hotels, and refraining from building huge complexes in the protected area." He adds: "to preserve the culture, a base of elite tourism is absolutely indispensable". ${ }^{22}$ The link between conservation and cultural or elite tourism also occurs in remarks of Milena Filipovic, a consultant at the Ministry of Culture: "there is still a tendency among some tourism

\footnotetext{
${ }^{21}$ Kotor, July 2006

${ }^{22}$ Budva, July 2006
} 
professionals to lean towards mass tourism, but if the culture and nature are to be protected it is essential to move in the direction of cultural tourism". ${ }^{23}$

It seems relevant to his present study to examine these two masterplan objectives: the desire to attract Western tourists and to promote a form of cultural tourism associated with quality services. Comments by Alama Henic Strahina from the tourism board echo these options: "There is a desire to promote cultural and nautical tourism for the Bay of Kotor and the surrounding area.(...) The target market is Western and Northern Europe, we have always been in contact with partners in these regions". ${ }^{24} \mathrm{From}$ this standpoint, cultural tourism is seen as a sort of safeguard ensuring the conservation of the site. Its development constitutes a brake on the growth of mass tourism, which would be harmful to the integrity of the site, as further remarks from Alma Henic Strahina make clear: "We are too small for mass tourism, which can only bring in short term profits. Cultural tourism is much more profitable for Kotor in the long term." 25

Although the development of cultural tourism in the region may be justified by conservation objectives, some actors, such as Kirsi Hyvärinen also from the tourism board of Montenegro are quite open about the interests based on the potential profits that this kind of activity may generate: "Although cultural tourism logically forms part of sustainable development, there is also of course an economic angle. Living standards cannot be raised solely through mass tourism. I think that economic criteria and criteria linked to long term development should be put on an equal footing." ${ }^{26}$ Prentice points out that tourists' interest in culture can influence the amount they spend at the site:"Tourists with particular cultural or historical interest for the site, or staying longer at a site, are more likely to make purchases inside the site." (1993: 153) In addition, says Nota Pantzou, the option of developing cultural tourism in Kotor is also influenced by a sort of identity assertion:

"Within twenty years the site attained different national connotations and significance. Montenegrins in their attempt to become sovereign, ascribe major importance to the development of cultural tourism and to the creation and projection of the Montenegrin cultural identity, in opposition to Serbian one." (2006: 3)

This raises the question, now that Montenegro is independent from its Serbian neighbor, of whether the opposition is not now taking place at a more local level, with a specifically Bokelian identity opposing a national identity, as inferred earlier. These examples show that different interests - conservation, profit or the assertion of identity - can influence the desire to promote cultural tourism in the site and that it can be a source of tensions. Katarina Nicolic sums it up well: "Cultural tourism certainly has an enormous development potential, but I think we are not yet ready. We do not have a strategy or adequate laws." She adds, referring to the masterplan: "It says very little about cultural heritage and conservation. It is just something that has to be done and no-one will do!" Concerning the future of the cultural heritage of the region she says she is "very skeptical. Our heritage attracts tourists, but tourism can be very bad and here we are not at all aware of the dangers."27 Alma Henic Strahina is also rather skeptical about the vision of many actors in the tourism industry: "Personally I would like more long term tourism and less mass tourism. I would like to see the adoption of a long term vision... but the current official vision seems to be "How can we open these markets with the less possible effort?"28

\section{Gentrification and Commercialization}

Tourism entities want to see the development of a type of elite tourism in the Kotor and the Bay of Risan site, which they equate with cultural tourism. According to ICMOS, this is made up of "highly desirable visitors (who) spend healthy sums of money" (1993, Site manager's handbook). As part of this process the price of services to tourists increases and the services themselves are adapted to meet the expectations of this new and manly Western clientele.

\footnotetext{
${ }^{23}$ Podgorica, August 2006

${ }^{24}$ Podgorica, July 2006

25 idem

${ }^{26}$ idem

${ }^{27}$ Podgorica, August, 2006

${ }^{28}$ Podgorica, July 2006
} 
Daniel Vander Gucht, see mass tourism as "the popular and democratic version of the Grand Tour, from which it draws its name" and the growing enthusiasm for cultural tourism as a reference to earlier cultural pilgrimages. Jean Baudrillard, analyzing the success of the Centre Pompidou in Paris, asks whether the rush of mass tourism to cultural centers will not put an end to the democratization of culture. The masses are, he says, "the catastrophe of Beaubourg. Their numbers, their stampede, their fascination with seeing and manipulating everything, constitutes deadly, catastrophic behavior for the entire undertaking. ... The mass acts as an agent of catastrophe" (1977: 26) In the Kotor context, the aim of assimilating cultural tourism with elite tourism, described above, could be seen as similar to the "segregation of museums that existed in the $19^{\text {th }}$ century, when visiting the Louvre was the privilege of a few wealthy tourists". as described by Patrice Beghain. (1998: 43). This last author maintains that this approach may be justified in the case of the Lascaux caves, for example, but queries whether elsewhere the motivation is for heritage considerations or commercial reasons:

"The heritage economy (...) if it is not to fall into democratic discredit, must not forget that its ultimate aim is not the cash register, but the construction of an individual and collective relationship with a tradition." (1998: 44)

If mass tourism is a democratic version of the Grand Tour, as the authors quoted above maintain, then the cultural tourism promoted in the Boka is by contrast a more selective and more faithful version of the Grand Tour. The article in Danass, quoted earlier, describes the settlement of the international jet set in the region; this echoes Vander Gucht's vision of the jet set's leisurely migrations as a continuation of the Grand Tour tradition. (2006: 105) The author points out that in modern society, as in the Ancien Régime, tourism is an important indicator of social status. Richard Prentice in his book asserts that heritage consumption is socially selective and "is a feature generally throughout the Western world". Does Kotor have a vision of tourism that makes a difference between a society of the masses and an upper-class society "that wants culture, judges and devalues cultural things like social goods, but does not consume them"? (Vander Gucht, 2006: 92) And on the other hand a mass society that is looking for relaxation, not culture? One can agree with Vander Gucht, who casts doubt on a "society of the masses", an idea based on an illusion of social homogeneity that logically would make the cultural tourism industry "leisure for the masses with a cultural base". (2006: 102) This is view partly shared by ICOMOS, which says cultural tourism "distinguishes itself from bad tourism and destructive tourism" (1993: VIII). But it adds that this definition is too moral to be useful: "The same tourist may in one day visit a World Heritage site and the next be found relaxing on a beach". (1993: VIII) In other words, it is difficult to define a homogeneous category of individuals motivated solely by cultural criteria and who would systematically correspond to the characteristics that a priori define cultural tourism. Finally it is important to remember that the development of cultural tourism is still in its early days. And the selection of tourists described earlier is essentially a phenomenon of those involved in tourism and the masterplan. Nevertheless the consequences are starting to be felt, as it has already been introduced. Moreover, according to ICOMOS, World Heritage Sites tend to become "high-price, hard-to-getinto attractions in the tourism world." (1993: IX) The selectivity of designated sites is thus explicitly expressed in this document.

\subsection{The desertification of town centers}

It's now time to take a look at some of the consequences for the site from a broader, socioeconomic perspective. The Boka region and more particularly its most important tourism sites are experiencing an increase in investments, mostly foreign, that are driving up real estate prices. Sasha Karajovic, chief planner for Montecep (the national branch of CEP, a Belgrade based urban planning company) explains: "Of course the main problem is in the old town of Kotor. There is a lot of talk about investments, but we never have any proof. Despite that, the price per square meter in the old town is now between two and three thousand Euros, compared to 1,000 Euros two years ago."29 This process, which is transforming some places into museum towns or dead towns, is also related to gentrification: "It's the social and economic take-over of an area by the well to do, a process that increases real estate values and displaces

\footnotetext{
${ }^{29}$ Kotor, August 2006
} 
the poorer inhabitants." (Smith, 1988). In an article published in UNESCO "World Heritage Cahiers" Pharès and Yang describe the process as follows:

"Certain areas undergo a gentrification process whereby they lose their original population and become touristic window displays or urban museums, without any neighborhood services or commercial activities or crafts. (2002: 9)

As it can be seen, the notions of gentrification and commercialization are linked; both are held responsible for the growth of "theme parks" or "urban museums". Beghain also stresses the influence of UNESCO which according to him, contributes to the process of transforming sites and living cultures into "theme parks for «homo touristicus»". (2006: 34). He maintains that "The «heritagisation» of the world, and the search for authenticity, are part of a project of community museology." (2006: 60) In the same vein, Vander Gucht sees a museumified world where heritage is colonizing living cultures:

"By museumising the world on the pretext of preserving its cultural heritage, cultural differences cancel each other out under the aesthetic gaze of the aesthete and cultures are reified...." (2006: 15)

This cultural colonization, he argues, is "brought about by generalized cultural tourism which makes us see everything, including our own culture, as a show, (...) for we now look on the world and on ourselves with a tourist's eyes." (2006: 16) Pharès adds that the protection of the urban tissue of a place calls for "a global strategy whose main guideline is the cultural identity of the town." (2002: 9). Similarly, Patrice Béghain points out that the protection of a site is not limited to the buildings:

"It is not solely the quality of the monument and its artistic or historical interest that matters, it is also the elements in the urban setting to which it is linked and which connect us to a history and to collective practices." (1998: 59)

These remarks demonstrate the importance their authors attach to "the identity of a place" shaped by "a history and collective practices." Cultural heritage is, as Pharès maintains, "the living heart of the identity of our towns". (2002: 9) However, that does not mean that conservation has to resist change, "but that change has to be evaluated and managed so that development is lasting, ecologically, culturally and socially." (2002: 15) Here Pharès comments that heritage protection policies tend to provide historic centers with material infrastructure, but take away their initial functions:

"As they undergo tourist development and gentrification, historic centers gradually lose (...) their function as a place to live, a function which after all is an integral part of the sites' value and of the criteria which led to their designation." (2002: 15)

Tamàs Fejérdy, president of the world heritage committee in 2002, states "historic centers are complex living entities; they are vulnerable to their own development". These comments all point to the difficulties of reconciling heritage protection and the development of tourism strategies and indicate some of the effects arising from the increasing attraction of a tourist site, including eventual damage to its image as a tourist destination. To some extent, it is a vicious circle: the preservation of a cultural identity may give added value to heritage buildings, but in the long run the added value can set off a gentrification process which constitutes a threat to this identity.

Some places within the framework of the study, such as Perast, which several interlocutors called a "shuttered town", have already undergone the process that transforms them into a museum-town and steadily drives all manifestations of ordinary life from public spaces. Lidija Liesar explained how it is happening to the historic centre of Kotor: "A big problem is foreign investment. The arrival of a lot of foreigners who buy homes that they only use during the tourist season has changed the demographic structure of Kotor. If this continues, Kotor will turn into a dead town! For the moment it is still a lively city with a town council, many shops and restaurants, a Faculty and people who live there all year round. But the way things are going, the old town will soon only be alive in summer." 30 This phenomenon leads ICOMOS

\footnotetext{
${ }^{30}$ Podgorica, August 2006
} 
representatives to affirm that there are more problems to be overcome in inhabited historic centers than in other sites:

"Historic towns which are still inhabited and which by their very nature have developed and will continue to develop under the influence of socio-economic and cultural change, represent a situation that renders the assessment of their authenticity more difficult and any conservation policy more problematical." (1993: 74)

In other words the conservation of historic centers is very complex because it has to deal with inhabited sites and ensure that they remain inhabited and alive. The population flight from tourist sites creates, according to Beghain, "reservations delivered up to the delights and poisons of cultural tourism, becoming sorts of heritage caravanserais." (1998: 63). for Vander Gucht, the challenge for both heritage and culture is to remain "alive, active and fertile and not to become disincarnate, embalmed.... in a word museumified". (2006: 8) The above comments indicate that the gentrification process that is bringing about the museumification of Kotor old town and places like Perast is not yet complete and that there still exists what some writers call "the spirit of place" (Yang, Pharès, 2002).

\section{Conclusion: A heritage to build a varied identity}

The main objective of this study was to shed light on the process of constructing or reinventing an identity and a cultural landscape at a regional level, by means that in many cases are linked to tourism. It aimed to demonstrate that behind the promotional image lies a desire to express or to showcase a specifically Bokelian element of identity. Depending on the objectives and the contexts, the attitudes of the actors in this identity building process can be very different and heritage seems to constitute a strong basis for it. As it has been demonstrated the use or the instrumentalisation of the region's heritage also varied and could cause conflict. In conclusion, it seems that identity is not homogeneous, but differs according to the context. It also seems clear that the discrepancy between the attitudes and representations of the tourism sector and what can be seen as the reality of the field is typical of the difficulties attached to determining a specific identity for a region. The process is even more complex if the site has been institutionalized by an organization such as UNESCO: other actors and interests automatically become involved. Having decided that the identity is fragmented and largely dependent on the different actors and contexts, one can set out to define these layers of identity and indicate their conflictual or consensual elements. The objective was also to show the different ways in which the Bokelian identity can be experienced and interpreted. At the same time, it was assumed that this identity do have common characteristics, like the importance of the seafaring tradition, the historical links to Venice, or the tolerant nature of the region. All these are notions that seem to be shared by the vast majority of the population.

This study does not pretend to offer solutions to some of the problems it identifies. Nor does it claim to resolve the question with any certainty of whether the Bokelian identity is authentic or simply a creation for the tourist market. It is nerveless relevant to highlight some of the issues involved in affirming or dissolving an identity, in a context of conservation and tourism development. To what extent are those involved in tourism selling a place's identity and thus turning huge areas into living museums? In Kotor one can see the over-exploitation and merchandising of its heritage. Heritage seems indeed often treated as a product to be marketed. Following this process the material heritage of Kotor is under threat from illegal urbanization, while its immaterial heritage is being undermined, as examples from the Summer Carnival, among others, show. The commercialization of certain elements in the region could harm tourism. Aspects that some consider as commercial and unauthentic could in the long term hamper so-called "cultural tourism". Moreover, development or the desire to promote cultural tourism does nothing to slow down the growth of mass tourism, which is seen by conservation professionals as a threat to the site's integrity. Using a place's identity - a key factor in attracting tourists looking for authenticity - for commercial ends tends to transform this identity into a superficial image aimed chiefly at the tourism market. Tourists visiting heritage sites want to enjoy an experience generated by the local culture. If this no longer exists, or only in a standardized version, then these tourists, generally the most affluent, will desert these sites and their over-popularity. This constructed place identity is linked to an "invented landscape" - 
a notion developed by Terkanli and introduced at the beginning of this paper - which can turn into a "normative landscape" as noted by Bender:

"More often than not, those involved in the conservation, preservation and mummification of landscape create normative landscapes, as through there was only one way of telling or experiencing. They attempt to freeze the landscape as palimpsest of past activity... Freezing time allows the landscape or monuments in it to be packaged, presented and turned into a museum exhibits." (1999: 26)

In conclusion a few propositions one line of enquiry interesting to pursue in the future will be proposed. As it has been demonstrated, and as many interlocutors confirmed, the development of tourism could represent a threat for the site. Further, the current "investment boom" in Kotor's region is turning the central areas and some secondary locations into urban or rural deserts outside the tourist season, threatening the life of those places and thus indirectly the "place's identity". If the Bokelian identity is in part linked to a place, it could be interesting to observe how it evolves in the future when growing numbers of people from distant cultures settle in the site. In other words, heritage is an issue with roots firmly in the present, and is not solely the domain of historians and conservationists. Its promotion, preservation and exploitation have to take into consideration the whole of society. A place initially reputed to be "magic" can be turned into a museum and become the victim of its own success. The extents to which Kotor's inhabitants are aware of this process will certainly determine the future of the site.

References

[1] Ascher, F. (1984). Tourisme, sociétés transnationales et identités culturelles, Presses de I'UNESCO.

[2] Ashworth, G. (2009). In search of the place identity divided: Using heritage landscape to create place identity. Ashgate

[3] Baudrillard, J. (1977). L'effet Beaubourg: Implosion et dissuasion (Débats), Editions Galilée.

[4] Beghain, P. (1999). Le patrimoine: culture et lien social, Presses de Sciences Po.

[5] Bender, B. (1999). Stonehenge: Making Space, Berg Publishers.

[6] DEG (2001). Touristic Masterplan for Montenegro: executive summary. DEG

[7] Frykman, J. (1999). Belonging in Europe: Modern identities in minds and places. Ethnologica Europeana

[8] Ciarcia G. (1998). Ethnologues et « Dogon ». La fabrication d'un patrimoine ethnographique. Editions Labor.

[9] ICOMOS (1993). Tourism at world heritage sites. The site manager's handbook. WTO

[10] Karajovic, S. (2005). Balancing of the development in Kotor Municipality. Montecep

[11] Montenegrin Ministry of Culture (2005). UNESCO World heritage sites in Montenegro.

[12] Müller, J. (2002). Memory and power in post-war Europe, Cambridge University Press.

[13] Pantzou, N. (2006). South Eastern Europe: homogenisation or cultural diversity? Global reflections, local perceptions. University of Southampton.

[14] Pedersen, A. (2002). Managing tourism at World Heritage Sites. A practical manual for World Heritage site managers. ICOMOS.

[15] Phares, J. \& Yang, M. (2002). La sauvegarde et le développement des villes du patrimoine mondial. Les Cahiers du Patrimoine Mondial 9

[16] Prentice, R. (1993). Tourism and Heritage Attractions, Routledge.

[17] Smith, N. (1986). Gentrification of the City, Unwin Hyman.

[18] UNESCO (2003). Cahiers du patrimoine 7, UNESCO 
[19] Vitic A. \& Ringer G. (2007). Branding post-conflicts destination: Recreating Montenegro after the disintegration of Yugoslavia. The Harvard press 